\title{
Gender Outlook on Advisory System, Entrepreneurship and Graduate Employability
}

\author{
Rohaiza Rokis \\ Department of Sociology and Anthropology, Kulliyyah of Islamic Revealed Knowledge and Human Sciences, International Islamic \\ University Malaysia, Kuala Lumpur, Malaysia \\ Email: rohaiza@iium.edu.my
}

How to cite this paper: Rokis, R. (2018). Gender Outlook on Advisory System, Entrepreneurship and Graduate Employability. Creative Education, 9, 2677-2692. https://doi.org/10.4236/ce.2018.916202

Received: September 14, 2018

Accepted: December 7, 2018

Published: December 10, 2018

Copyright (c) 2018 by author and Scientific Research Publishing Inc. This work is licensed under the Creative Commons Attribution International License (CC BY 4.0).

http://creativecommons.org/licenses/by/4.0/

\begin{abstract}
Unemployment is higher among young workers, particularly females. Part of the solution rests at the tertiary levels. The article views that undergraduates must have career knowledge, particularly in entrepreneurship, upon their graduation. This can be achieved through students' advisory system at each university. The International Islamic University Malaysia (IIUM) is chosen as a case. The research is conducted in the view that IIUM's advisory system is not used to the maximum. The mentors (teachers/lecturers) and mentees (undergraduates) are not really able to utilize the advisory system in the most effective way. It has an unfixed sense of connectedness in the life of the undergraduates. This situation may lead them graduated unprepared for the employment. Thus, it is sensible to investigate the possibility of utilizing the IIUM's advisory system towards employment prospects, using entrepreneurship modules for the benefits of female and male students. The samples are chosen among IIUM students within the age group of 22 to 26 for survey and interview designs. The design of the survey is to obtain statistics that describes particular descriptive aspects of the students, entrepreneurship embedded content in the academic program and the advisory system. In addition, the design of the interview is to capture the qualitative opinions of the students in regards to their aspiration in career upon graduation through the advisory system. This research concludes that an effective advisory system leads to career planning and employment chances particularly entrepreneurship among female graduates. The advisory system must foster the culture of connectedness between mentor-mentee in entrepreneurial skills for greater undergraduate employability prospects.
\end{abstract}

\section{Keywords}

Advisory System, Career Aspiration, Culture of Connectedness, Entrepreneurship, Gender, Mentor-Mentee, Undergraduate Employability 


\section{Introduction}

Students' advisory system is important in academic programs. Evidently, many universities and tertiary learning centers around the world apply the system particularly to the undergraduate program. Undergraduates are young adults who need guidance not only in academic, but also in communication, community sensitivity, and also employment. Advisory may enhance students' academic performance and skills development appropriately for females and males. Current employment pattern requires changes to accommodate the flexible and mobile workforce that supports knowledge-age.

The research deals with the advisory system at higher education. It utilizes the available advisory system to broaden students' career path. A fully functional advisory system depends on a manifest mission in initiating positive environment to students so that they may get inspiration in achieving their career vision. Consequently, the mentors must understand the youth workforce issues. In the end, the research may be able to suggest career realignment towards entrepreneurial activities among young people. To be creative in creating new jobs and not succumbing to the few existing ones are essential for them. The changing nature of work means that young workers are most likely to face is the prospect of a career shift from the paid employment to self-employment. The research aims to provide useful insights for the promotion of entrepreneurship among youths.

The research believes that entrepreneurship is the future employment opportunity. This is possible because everyone regardless of gender has entrepreneurial potentials yet to be released. If the conventional, formal jobs are extremely competitive to get today, young people, female graduates, other people of limited employment opportunity must be ushered to make use of their hidden talents and skills. In most college/university environment, an advisory system is one of the key components of an academic program. The responsibilities of identifying these unrecognized, unused and underdeveloped talents and skills may be in the hand of the mentors.

\subsection{Research Problem}

Many types of research conducted on youths and employment in Malaysia managed to understand the negative inter-relationship of the various employment issues among Malaysian youths (Fatimah, 2007; Rohaiza, 2014a). This study searches for an in-depth understanding of the issue and finds ways to reduce employment problems among young people. Students' advisory system are seen to be the ways to resolve the issue by exploring some new directions in youth career development to enhance employability among them. Entrepreneurship is one option to venture in. Whether or not young people have entrepreneurial attitudes, inclination and norms are worthy to be investigated.

\subsection{Research Proposition/Hypothesis}

Proposition/hypothesis 1: The entrepreneurship content in the University's ad- 
visory system may contribute to the career planning of female and male graduates.

Proposition/hypothesis 2: Entrepreneurial attitude and inclination is different between genders.

Among the items were asked: What is the opinion of IIUM students toward the effectiveness of advisory system? How the person-environment elements in the advisory system influence the students, both female and male? What is the possibility of assigning entrepreneurship modules within the advisory system?

Deriving from these questions, this research put forth major objectives that include: To understand the effectiveness of the advisory system; to identify person-environment elements in the advisory system, particularly based on gender perspectives; and to look into the possibility of assigning entrepreneurship modules within the advisory system.

The qualitative data is designed to capture the specific needs of the students towards the advisory system. Their opinions are then be interpreted to improve the present advisory system in the form of research suggestions.

\section{Methodology}

The survey is both quantitative and qualitative in nature. The quantitative data are based on the self-administered survey questionnaire via convenience sampling and web assistance. Prior to the actual data collection period, a pilot study was conducted on eighteen students. It enabled to ensure the questionnaire items precision. For the survey, data analysis was conducted using SPSS WIN 18.0. The analyses were mostly descriptive statistics in order to get the frequencies, percentages, means and standard deviations. There is no advance statistical analysis was conducted due to its non-probability sampling.

The qualitative data are based on the semi-structured interviews with IIUM students. The objective of the interview is to gain as much as possible some pertinent information in relation to students' entrepreneurial elements and employment. Prior to the real interview session, mock interviews were conducted to three students for interview items suitability. For the semi-structured interview, the analysis was assisted by Atlas.ti 7. The analyses were based on particular themes surface from the responses given by the interviewees. This thematic coding analysis complements the statistical analysis in many ways.

\section{Operational Definition}

This research concentrates on entrepreneurship skills among IIUM students. Nowadays, there is a significant necessity for graduates to create jobs rather than succumb to the existing yet uncertain ones. Being entrepreneurs is one of the solutions available. The research considers three related words of Entrepreneur, Entrepreneurial, and Entrepreneurship from the Dictionary of the English Language (1996). Their meanings are:

- Entrepreneur is a person who takes commercial risk of starting up and run- 
ning a business enterprise.

- Entrepreneurial is an adjective of a person who dares to take the commercial risk of starting up and running a business enterprise.

- Entrepreneurship involves initiating and managing a business endeavor.

\section{Conceptual Framework}

This paper is a research-based that considers specific social concepts that relate to an advisory system and college/university students leading to their employment prospect particularly towards entrepreneurship.

\subsection{Youth Employment and Employability in Malaysia}

Youth compared to adults are almost three times as likely to be unemployed (International Labour Organisation, 2001). This indicates that youth faces specific difficulties in the labor market (Leidenberger \& Stoltz-Loike, 2009).

Literature and statistics shows that the high youth unemployment is due to the relatively high retrenchment rate of young workers due to their lack of experience (Rashid et al., 2006; Baskaran, 2009; Chew, 2005; United Nations Statistics Division, 2001; Shukran et al., 2004). Furthermore, both developed and developing countries are failing to increase employment opportunities for young people (International Labour Organisation, 2001). In addition, on average young females are more likely to be unemployed than young males. The United Nations Statistics Division report (2001) also indicated that females were consistently higher than males to be unemployed.

Issues of unemployment in Malaysia remained unsolved since it first started to receive a public attention in the 1960s (Ahmad, 1998). The intensifying unemployment rate of the graduates of public universities disturbs Malaysian quality of life. Table 1 shows the data in Malaysia whereby youth aged 15 to 24 years formed the highest proportion of the unemployed between 1998 and 2014 for both sexes (whenever available).

Starting from 2015 until 2019, the researcher could only obtain a comparable unemployment data by age group but not by sex. But suffice to record at the

Table 1. Distribution of unemployed youths by age group and by sex from years 1998 to 2018 in Malaysia.

\begin{tabular}{|c|c|c|c|c|c|c|c|c|c|c|c|c|c|}
\hline \multirow{2}{*}{$\begin{array}{c}\text { Age Group } \\
\text { and Sex } \\
\text { (by percentage) }\end{array}$} & \multicolumn{13}{|c|}{ Unemployed Youth in Malaysia (1998-2018) } \\
\hline & *1998 & *1999 & $* 2000$ & *2007 & ${ }^{*} 2008$ & $* 2010$ & \#2012 & ${ }^{\#} 2013$ & \#2014 & $=2015$ & $=2016$ & $=2017$ & $=2018$ \\
\hline \multicolumn{14}{|l|}{ Both sexes } \\
\hline $15-24$ & 7.0 & 8.5 & 8.3 & 9.3 & 11.3 & 11.3 & 12.1 & 10.9 & 11.1 & 15.7 & 15.9 & 15.9 & NA \\
\hline \multicolumn{14}{|l|}{ Male } \\
\hline $15-24$ & 8.6 & 10.0 & 8.3 & 10.7 & 11.9 & 11.8 & NA & NA & NA & NA & NA & NA & NA \\
\hline \multicolumn{14}{|l|}{ Female } \\
\hline $15-24$ & 8.8 & 9.2 & 8.3 & 11.5 & 11.8 & 10.3 & NA & NA & NA & NA & NA & NA & NA \\
\hline
\end{tabular}

Sources: ${ }^{*}$ United Nations Statistics Division, 2010; ${ }^{*}$ United Nations Statistics Division, 2015; International Labour Organisation. 
moment the employment rate of male in 2017 is $61.5 \%$ in comparison to only 38.5\% for female (https://www.humanresourcesonline.net/malaysias-workforce).

Malaysia produces more children to universities but apparently it fails to get them into productive employment. More ironic is the fact that universities produce exceeding number of female graduants than male every year (Rashid, 2006). Government's investment in education and training will be useless if young people do not move into productive jobs that enable them to support themselves, contribute to their families' earnings, and pay their publicobligations. However, not many in-depth discussions are available on youth perceptions, attitudes, values, and behaviors that can be explored to enhance their job prospects and entrepreneurial skills.

\subsection{Advisory System at Higher Education}

In relation to the aspiration of the government, IIUM may also strives to reduce the unemployment rate among its graduates. Advisory system may be one mechanism. According to David Hamburg, President, the Carnegie Corporation of America, "Every college and university in the nation should have a strong, substantive, explicit, functional linkage with schools in its geographical area".

In recent years in many western higher education, an advisory system has emerged as a response to youth at-risk. The mentoring program on campus-based is either students' peers or teacher/lecturer become the mentor. They act as both a friend and role model who supports and encourages their mentee in her/his academic and personal growth. The mentor serves as a guide who helps a mentee in making an adjustment in academic and social life at the college/university.

The Hatfield College of the Durham University, England uses a different strategy from IIUM. Its college mentor is not a teacher/lecturer who can advise on the content of mentees' academic work. Instead, she or he can be any staff of the university who helps mentees to reflect on and record any progress. The college ensures all freshies is given booklet on SHAPED (or Supporting Hatfield's Academic Progress, Employment, and Development). The booklet has full details of the SHAPED program for the year. Not only it provides the day-to-day entries for academic commitments, it also has key dates in the academic and community life of Hatfield

(https://www.dur.ac.uk/hatfield.college/undergraduate/support/).

In the Asian region, the Hong Kong University (HKU) Mentorship Program is commendable. Every year 500 pairs of mentors (among friends and alumni of the University) and mentees (among HKU second-year undergraduates, Exchange Students or Year 3 students following a 4- or 5-year curriculum) are matched. Liaising alumni with students has proven to be a fruitful project, particularly about establishing employment network.

The success of the advisory system depends on the two-way mentoring relationship. The mentor is expected to engage with the mentees through a framework of mentor-led activity. The mentees, in turn, are expected to develop a 
professional but friendly relationship with her/him. At Durham University, if the mentoring program faces relationship breaks down, mentors and mentees are expected to bring the issues to the attention of the Senior Tutor. Indicatively, a clear directive apparatus is made available for any mishandling occasions in the advisory system. Thus, the advisory system is not a "time-wasting" session.

The best practice of advisory system that is currently in action lies on a clear objective for a personal development program with the goal of increasing the employability of its students. St Cuthbert College at Durham University, England, for instance, structured the system by naming a college mentor who can be contacted if the first year mentees are confused about anything to do with the college or the University. When the mentees get into the second year and beyond, they will be directed to the weekly Students' Development and Employability Program. This is a very important program that involves speakers from the academic community, college staff, alumni, the Senior Common Room and local and national contacts.

With a sound objective to increase employability, the advisory system will definitely find its relevance and usefulness. One of the functions of the advisory system is initiated entrepreneurship program for students.

\subsection{Knowledge-Based Economy, Entrepreneurship, and Higher Education}

Entrepreneurship is the capacity and willingness to develop, organize and manage a business venture alongside any risks it may involve in order to make a profit. (http://www.businessdictionary.com/definition/entrepreneurship.html). The knowledge-based economy is an economic transition of the advanced industrial nations. The current economy requires for new ideas and novel technology, in which knowledge-based economic activity is able to provide. Entrepreneurship is seen essential now. Entrepreneurial economy promotes human fulfillment as it enables a greater degree of creativity, autonomy, and independence (International Labour Office, 2005).

An analysis of empirical data reveals that entrepreneurship remedies the unemployment problem. Audretsch, Carree and Thurik (2001) found that innovation efforts have an indirect effect on economic performance via entrepreneurship. More recently, the term entrepreneurship has been extended to include an entrepreneurial mentality that brings in entrepreneurial initiatives such as innovative efforts (http://papers.ssrn.com/sol3/papers.cfm?abstract_id=1510006). Prospering entrepreneurial mentality is the gap that colleges/universities can provide to connect graduates to employment. Earlier work of Audretsch and Thurik (1998) found the role of globalization and the knowledge-based economy as causes of increased entrepreneurship. They uncovered a two-way causation between entrepreneurship and unemployment. Their finding showed a strong link of: 1) increased entrepreneurship decreases unemployment; 2) increased unemployment stimulates entrepreneurship.

Within the Malaysian context, Mohamed and Syarisa (2011) found that atti- 
tudes toward entrepreneurship have been previously divided along racial division due to the "divide-and-rule" economic policy of the British colonialized period. Historically, the Chinese and some Indian-Muslim communities have been practicing entrepreneurship. Yet, it was not for the Bumiputera (or literally means "sons of the soil"). In general, the Malays and indigenous peoples of Peninsular Malaysia, Sabah, and Sarawak did not have entrepreneurship tradition. Rather, they were used to being either employed in the government service or self-employed as agricultural farmers or smallholders. Nevertheless, there were few exceptions where women in Kelantan have traditionally worked as petty traders in the markets. Until today, the situation begins to change as the whole of Malaysian society modernizes and social restructuring takes effect (Chong, 2010; Lai, 2010).

Entrepreneurship program at college/university requires a particular strategy which is different from corporate strategy. To make it effective, the mentoring program may instill ideas to college/university students to emulate the substantial idea of entrepreneurship that is to develop, organize and manage a business venture alongside any risks it may involve for profit-making. Instilling attitudes of entrepreneurs who are resistance to risks and resilient to shortcomings while ambitious for money is significant (Bolton \& Thomson, 2000; Rugaber, 2010).

\section{Theoretical Framework: Social Theory of Youth Empowerment}

The social theory of youth empowerment (Jennings et al., 2006) deliberates social interactions issues among young people, and how those social interactions can be used to empower them to enhance productivity. This theory emphasizes the process of empowerment through the participation of the community particularly the significant adults in the family, school as well as employers. This theory highlights a positive bonding that may produce opportunities between youth and adults within a safe and supportive environment.

Instead of individual effort, this theory believes in the joint effort in nurturing a healthy youth empowerment and development. Because today's youth are exposed to the risk of unhealthy social behaviors, this theory therefore suggests their positive involvement with larger community.

\section{Analyses and Findings}

The survey received 246 respondents, with a fair distribution of female $(n=108)$ and male $(n=138)$. With the exception of demographic items, the question relies on the agreement level of the respondents toward statements that represent their attitudes about the advisory system and entrepreneurship. Their views are measured by the 5-Likert scale of "Not applicable (0)"; "Strongly agree (1)"; "Agree (2)"; "Disagree (3)"; and "Strongly disagree (4)". The interview collects 10 interviewees with 5 females and 5 males. Whenever possible, the qualitative 
data from the interview excerpts are also included to strengthen the available quantitative findings.

Having entrepreneur skills need to be inspired at the University level. It is, therefore, important to relate to students' advisory system of the University. Based on this spectrum, this research set a proposition/hypothesis to link up students, entrepreneurship and, advisory system.

Based on proposition/hypothesis 1: The entrepreneurship content in the University's advisory system may contribute to the career planning of graduates. The research set some relevant questionnaire items.

The finding indicates the respondents, of both genders, highly agreed that IIUM students' advisory system should have items for entrepreneurship content ranging $(M=3.98-1.97, S D=0.83-0.63)$ at $92.3 \%-39.8 \%$. Comparing gender, it is found that female scored better in 6 items (Table 2).

Additionally, almost all interviewees want IIUM should include entrepreneurship content in the advisory system. They believe this initiative would benefit them to prepare for future employment prospects. A male interviewee said:

"The advisory system must have entrepreneurship syllabus to make it useful. At the moment, I think this advisory system is just a waste of time without a clear purpose rather than just to 'hi' to my mentor. But if I have some clear purpose of meeting such as discussing on entrepreneurship, then meeting the mentors can be good".

Likewise, a female interviewee viewed:

Table 2. Recommended items for entrepreneurship content in IIUM students' advisory system based on genders.

\begin{tabular}{|c|c|c|c|}
\hline $\begin{array}{c}\text { Items } \\
(N=246): \text { Female }(n=108) ; \text { Male }(n=138)\end{array}$ & $\begin{array}{l}\text { Male } \\
\text { Agreement } \\
(M, S D)\end{array}$ & $\begin{array}{l}\text { Female } \\
\text { Agreement } \\
(M, S D)\end{array}$ & $\begin{array}{c}\text { Overall } \\
\text { Agreement } \\
\text { (Percentage) }\end{array}$ \\
\hline $\begin{array}{l}\text { I think career advisory at IIUM must have } \\
\text { mentors who know a lot about what } \\
\text { it takes to be entrepreneurs }\end{array}$ & $\begin{array}{l}M=1.77 \\
S D=0.45\end{array}$ & $\begin{array}{l}M=1.03 \\
S D=0.58\end{array}$ & 99.2 \\
\hline $\begin{array}{l}\text { I think career advisory at IIUM must } \\
\text { develop entrepreneurial skills among students }\end{array}$ & $\begin{array}{l}M=1.50 \\
S D=0.67\end{array}$ & $\begin{array}{l}M=1.45 \\
S D=0.48\end{array}$ & 98.8 \\
\hline $\begin{array}{l}\text { I think career advisory at IIUM must organize } \\
\text { career consultations on entrepreneurship for students }\end{array}$ & $\begin{array}{l}M=1.75 \\
S D=0.56\end{array}$ & $\begin{array}{l}M=1.04 \\
S D=0.43\end{array}$ & \\
\hline $\begin{array}{l}\text { I think career advisory at IIUM must encourage } \\
\text { students to develop creative ideas } \\
\text { to be an entrepreneur }\end{array}$ & $\begin{array}{l}M=1.75 \\
S D=0.57\end{array}$ & $\begin{array}{l}M=1.41 \\
S D=0.43\end{array}$ & 94.7 \\
\hline $\begin{array}{l}\text { I think career advisory at IIUM must suggest } \\
\text { the University subjects/courses that are } \\
\text { related to entrepreneurship for students }\end{array}$ & $\begin{array}{l}M=1.67 \\
S D=0.63\end{array}$ & $\begin{array}{l}M=1.07 \\
S D=0.44\end{array}$ & 91.5 \\
\hline $\begin{array}{l}\text { I think career advisory at IIUM must include } \\
\text { entrepreneurship advice for students }\end{array}$ & $\begin{array}{l}M=2.78 \\
S D=0.54\end{array}$ & $\begin{array}{l}M=2.56 \\
S D=0.79\end{array}$ & 88.6 \\
\hline
\end{tabular}

*Scale: "Not applicable (0)"; "Strongly agree (1)"; "Agree (2)"; "Disagree (3)"; and "Strongly disagree (4)". 
"I feel shy to see my mentor (because) I do not have anything to say. Even if I have any academic issues, I usually discuss it immediately after class. (But) If I have other issues talking my future like entrepreneurship opportunity, then I may feel more comfortable to meet him. The (advisory) system must be improved".

Approaching to proposition/hypothesis 2 about entrepreneurial inclination based on genders, it is found that female respondents are more disinclined to possess entrepreneurial attitudes than male respondents, with a percentage ranging from $78.9 \%-87.4 \%(M=1.97-3.34, S D=0.63$ - 0.75) (Table 3$)$.

Interestingly, the findings also found that respondents coined being an entrepreneur to religion. Islam is seen as a mediating element to be successful in life. Both genders seem to agree on the item I want to be an entrepreneur because it is fardhukifayah (an obligation) to be successful Muslims in this material world. Achieving success by becoming an entrepreneur is considered as fardhukifayah (an obligation) for every Muslim. Thus it motivates people to be entrepreneurs so that other Muslim may get benefits from them. One male interviewee elaborated:

"The Muslims must be successful in life. The best way is of course by doing business. This has been exemplified by Prophet Muhammad SAW. And among the Arab women during his time, Siti Khadijah RA is the most excellent women trader. We, the Muslims of today must follow their footsteps involving ourselves in business".

However, the specific gender-wise statistical finding shows a different presentation (See Table 4). Female respondents are less appreciating for positive self-ability qualities such as making own decision, liking the challenge, having independence, among others. This data shows that females are less likely than males to agree on having entrepreneurial attitudes, except doing on-line business, in which female respondent scored better $(M=2.05, S D=0.54)$ as compared to males' $(M=3.07, S D=0.73)$ at $67.1 \%$.

Table 3. Entrepreneurial attitudes based on gender.

\begin{tabular}{|c|c|c|c|}
\hline $\begin{array}{c}\text { Items } \\
(N=246): \text { Female }(n=108) ; \text { Male }(n=138)\end{array}$ & $\begin{array}{l}\text { Male } \\
\text { Agreement } \\
(M, S D)\end{array}$ & $\begin{array}{l}\text { Female } \\
\text { Agreement } \\
(M, S D)\end{array}$ & $\begin{array}{c}\text { Overall } \\
\text { Agreement } \\
\text { (Percentage) }\end{array}$ \\
\hline $\begin{array}{l}\text { I want to be an entrepreneur because } \\
\text { I can make my own decisions }\end{array}$ & $\begin{array}{l}M=2.32 \\
S D=0.69\end{array}$ & $\begin{array}{l}M=3.08 \\
S D=0.70\end{array}$ & 87.4 \\
\hline $\begin{array}{l}\text { I want to be an entrepreneur to challenge } \\
\text { my capabilities }\end{array}$ & $\begin{array}{l}M=2.22 \\
S D=0.75\end{array}$ & $\begin{array}{l}M=3.34 \\
S D=0.75\end{array}$ & 86.6 \\
\hline $\begin{array}{l}\text { I want to be an entrepreneur for it offers } \\
\text { independence }\end{array}$ & $\begin{array}{l}M=2.77 \\
S D=0.65\end{array}$ & $\begin{array}{l}M=2.93 \\
S D=0.68\end{array}$ & 84.1 \\
\hline I want to be an entrepreneur for self-satisfaction & $\begin{array}{l}M=2.50 \\
S D=0.67\end{array}$ & $\begin{array}{l}M=2.99 \\
S D=0.78\end{array}$ & 80.1 \\
\hline $\begin{array}{l}\text { I want to be an entrepreneur because } \\
\text { I do not like to work under other people }\end{array}$ & $\begin{array}{l}M=1.97 \\
S D=0.63\end{array}$ & $\begin{array}{l}M=2.98 \\
S D=0.75\end{array}$ & 78.9 \\
\hline
\end{tabular}

*Scale: "Not applicable (0)"; "Strongly agree (1)"; "Agree (2)"; "Disagree (3)"; and "Strongly disagree (4)". 
Table 4. Entrepreneurial inclination based on gender.

\begin{tabular}{|c|c|c|c|}
\hline $\begin{array}{c}\text { Items } \\
(N=246): \text { Female }(n=108) ; \text { Male }(n=138)\end{array}$ & $\begin{array}{c}\text { Male } \\
\text { Agreement } \\
(M, S D)\end{array}$ & $\begin{array}{c}\text { Female } \\
\text { Agreement } \\
(M, S D)\end{array}$ & $\begin{array}{c}\text { Overall } \\
\text { Agreement } \\
\text { (Percentage) }\end{array}$ \\
\hline $\begin{array}{l}\text { I will make every effort to start and run } \\
\text { my own business }\end{array}$ & $\begin{array}{l}M=2.75 \\
S D=0.63\end{array}$ & $\begin{array}{l}M=3.23 \\
S D=0.83\end{array}$ & 86.2 \\
\hline I will choose a career as an entrepreneur & $\begin{array}{l}M=2.22 \\
S D=0.55\end{array}$ & $\begin{array}{l}M=3.34 \\
S D=0.75\end{array}$ & 84.6 \\
\hline I will be an entrepreneur as I am not afraid of failing & $\begin{array}{l}M=3.03 \\
S D=0.75\end{array}$ & $\begin{array}{l}M=3.84 \\
S D=0.88\end{array}$ & 84.1 \\
\hline I will start a business whenever opportunity comes & $\begin{array}{l}M=2.50 \\
S D=0.67\end{array}$ & $\begin{array}{l}M=3.45 \\
S D=0.78\end{array}$ & 75.6 \\
\hline I will start my business upon completing my study & $\begin{array}{l}M=3.33 \\
S D=0.63\end{array}$ & $\begin{array}{l}M=3.90 \\
S D=0.85\end{array}$ & 73.6 \\
\hline $\begin{array}{l}\text { I will start a business if I have all the resources } \\
\text { such as money, skills, networks, etc. }\end{array}$ & $\begin{array}{l}M=1.95 \\
S D=0.66\end{array}$ & $\begin{array}{l}M=3.04 \\
S D=0.83\end{array}$ & 73.2 \\
\hline I am prepared to be an entrepreneur & $\begin{array}{l}M=3.33 \\
S D=0.73\end{array}$ & $\begin{array}{l}M=3.99 \\
S D=0.86\end{array}$ & 72.4 \\
\hline I will be an entrepreneur as it is not a risky career & $\begin{array}{l}M=3.75 \\
S D=0.79\end{array}$ & $\begin{array}{l}M=3.87 \\
S D=0.83\end{array}$ & 68.7 \\
\hline I will do business at home such as on-line business & $\begin{array}{l}M=3.07 \\
S D=0.73\end{array}$ & $\begin{array}{l}M=2.05 \\
S D=0.54\end{array}$ & 67.1 \\
\hline $\begin{array}{l}\text { I will be an entrepreneur as it provides } \\
\text { non-office employment }\end{array}$ & $\begin{array}{l}M=2.75 \\
S D=0.63\end{array}$ & $\begin{array}{l}M=3.73 \\
S D=0.83\end{array}$ & 55.7 \\
\hline
\end{tabular}

*Scale: "Not applicable (0)"; "Strongly agree (1)"; “Agree (2)"; "Disagree (3)"; and "Strongly disagree (4)".

One female interviewee represents the voices of others by commenting:

"No, I will not be (an) entrepreneur. It is too risky. I want to work in a more comfort and easy way. But looking at that again, the on-line business may be less risky. I may get involved part time. It is after all quite normal today to shave some extra money". But a male has a different view: "On-line business is just not me. If I ever involve in business, it must be a real business, a normal kind of business".

Female respondents are less likely to agree on almost all statements on entrepreneurial attitudes and entrepreneurial inclination. The responses from male respondents appear to have more attitudes and inclination towards entrepreneurship. However, they are less likely willing to do business at home such as on-line business than female counterpart. An excerpt has nicely given by one female interviewee. She said:

"I want to work in a real working environment. Becoming (an) entrepreneur is not what I have in mind. I am more interested to get the kind of jobs that will support my personal family in future (upon marriage). In this economic demanding situation, becoming entrepreneurs is not a good decision. It (entrepreneurship) is just too risky". On the other hand, a male interviewee had a contrasted view on entrepreneurship. This is what he said: "In such demanding 
economic world today, entrepreneurship is definitely an option because more money (financial sources) comes from doing business. We cannot rely on such a small income today. Life will be difficult".

The data found that most respondents do not have good entrepreneur role model. Both data confirmed on that. The discourse acquired an understanding that both female and male students believe that economic instability relates to entrepreneurship, but differed in their strategy. The females prefer to play safe in the comfort zone, whilst males look forward to employment risk and challenge. This finding may illuminate how gender influences different attitude towards entrepreneurship.

\section{Suggestive Comments to Better Enhance Advisory System}

The research deals with the advisory system at higher education leading to the promotion of entrepreneurship program among students. In a long run, the study wishes to provide a set of policy recommendations that can contribute to the creation of committed and dedicated graduate entrepreneurs who are willing to work outside the formal sector. At the same time, it helps others to secure quality jobs, thereby reducing unemployment, under-employment and the numbers of young people living and working in poverty.

This suggestion part derives from further comments received from interview sessions with the undergraduates who involve in this research project. The comments are interpreted and reported within the style of suggestions, for the benefits of the institution in the form of policy implications.

\subsection{Sidestepping the Superficiality of the Mentor-Mentee System}

The current practice of advisory system at some departments and kulliyyah (faculties) in IIUM is quite superficial. The mentor-mentee meetings (if any) is just about academic matters. If the system is made compulsory for a fixed meeting schedule, there is no penalty whatsoever for not adhering to the schedule. In the end, mentors and mentees do not feel obliged to observe the system. After all, the academic matters can always be discussed during the class sessions or afterward. No need to have a special mentor-mentee meeting.

To make the advisory system efficient, IIUM needs to have a proper guide for all mentors on utmost aspects that are important for mentees. At the end of their days, IIUM students will search for jobs. They need guidance and mentoring on career and employability aspect. Thus, it the mentors should be equipped with career information and employment opportunities to benefit the mentees. Many respondents especially males are interested to be entrepreneurs, and some of them had attended entrepreneurial courses/programs which were conducted by IIUM, but not so much by females.

\subsection{Providing Advisory Modules}

IIUM must have planned advisory modules for mentors. The modules must in- 
clude career awareness program, training of employability skills, coordinating placement/attachment; and campus recruitment. The mentors are suggested to integrate employability into the curriculum through experiential learning. Suggestively, mentees are to be introduced with soft skills for example personality enhancement course. In addition, attachment program and industry work experience must be expanded in the advisory system. Unceasing dialogue and cooperation with industry are ultimate indispensables.

At the same time, more career talks must be initiated in the advisory system. IIUM can impose all students' societies and associations to conduct career talks and organize career fair as an annual event that requires compulsory attendance and participation of third and final year students. Among the content of such talks is to provide mindfulness about building employability "profiles" or "portfolios" which supply a more accurate picture of the student's command of the skills and traits employers value.

\subsection{Updating Alumni List for Mentoring Program}

In addition, IIUM must have the updated list of alumni. The university's mentors should receive cooperation from alumni as a mentor. This may benefit mentees because they have the chance to a direct lesson from alumni-mentors, who are professionals and experts from different walks of life. It is a structured trio-basis relationship between a mentor, alumni-mentor and mentee. The strategy is a cross-discipline matching to give mentor, alumni-mentor and mentee the opportunities to learn from their unique alliance towards having the value of entrepreneurship. This effort is particularly appropriate for non-business students. They still do not think of entrepreneurship as a viable career alternative for them.

\subsection{Initiating Career Planning Program}

Solid employment with guaranteed pay slips is uncertain these days. It is suggested for IIUM advisory system to take account of career planning program for students. This strategy is definitely relevant to mentees who have entrepreneurship attitudes, which may open up varieties of personal employment chances. Thus, IIUM advisory system is recommended to include employment syllabus that brings in creativity to students. They have to be creative to develop their career path. For example, entrepreneurship and information and communication technology (ICT) that changed all aspects of the world today (Dangolani, 2011).

\subsection{Increasing Female Graduates' Employability and Work Empowerment}

Looking from gender context, the current data illustrates gender aspect on employability and inclination towards entrepreneurship. Higher learning centers in Malaysia produced graduates, both males and females, each year. However, it a normal scenario now that female university students outperformed educational attainment over their males' counterparts (Wye \& Rahmah, 2010). In spite of 
that, MohdLazim (2009) has found that unemployment among female graduates is still higher than males.

If IIUM wishes to see further improvement on graduates' employment rate, issues on female graduates and employment must be attentively addressed. Since the population of female graduates at IIUM is always exceeding male graduates, their disappearances in the employment sector influence the IIUM graduates' employment rate. Thus, mentors must have a clear employment plan for female mentees. If working at the established institutions is not their preference, these female mentees may be directed for self-employment.

IIUM support is invaluable for a project like this. The entrepreneurship program must be buttressed by active initiatives embedded within the advisory system. As long as IIUM provides endless support to fundraising, connecting mentor-alumni with mentees, the graduates who cannot find jobs, may create ones.

\section{Discussions and Conclusion}

In retrospect, the research is convinced that the advisory system is the best mechanism to create a person-environment element that can be utilized towards enriching employability among students at higher education. It further suggests the system to be operated within the structural module of entrepreneurship. Based on the social theory of youth empowerment (Jennings et al., 2006), mentors must empower mentees to express their interests in employment and bring out for action.

Labor market depends on the need for youth to be diverse in skills and attitudes. It requires "skills beyond subject knowledge" that not only to secure a job but also to be effective in it. Today's demand is for youth to be "ready for work" with clear evidence of job specific skills. Essentially, it is about having particular kind of attitudes that will make them employable.

Employability tends to have a variety of meanings ranging from the employment rates of youth from an institution to the characteristics of an individual youth. However, for this study, employability is about the potentials or attributes of the individual to obtain fulfilling work (Fatimah, 2007; Marohani, 2006) or the capability of being employed in a job (Shukran et al., 2004). The basic understanding about employability is developing a range of attributes that allows a graduate to get a job and be successful at it. Employability is thus about the ability to be employed (Hamisah, 2008).

Employability is especially linked to the institutional structure of a society such as schools, universities and other higher education centers. They provide a range of implicit and explicit opportunities, which includes theoretical-practical knowledge in getting jobs to youth. Developing young people's employability is an important policy issue for ensuring their successful transition to the labor market and their access to career-oriented employment (Jennings et al., 2006; Montross et al., 2004).

Many school leavers in Malaysia enter the labor market unprepared (Rashid, 
2006) and possessed dysfunctional behaviors (Rabiatul \& Intan, 2007) that include becoming criminals and law violators; substance abusers; political extremists. Deficiency of the right work attitudes required by the labor market made young people less employable (Fatimah, 2007; Rohaiza, 2014a).

Additionally, Chew et al. (1995) also found that they have twisted expectations of labor market that delay them to be employed. The problem is partly attributable to the fact that education and training systems often offer curricula that are irrelevant to the needs of the labor market. Also, it is further aggravated by the lack of proper career guidance and counseling in the educational institutions (Rusch, 2008). Specifically, due to lack of encouragement and some social constraints, young women become discouraged and gave up actively looking for work (Rohaiza et al., 2014b).

The cost of lost production and wasted human potential to economic and social development is extremely high, not just to the young people themselves but also to their families, societies and economies (Baskaran, 2009). As a successful developing country, Malaysia must ensure that it receives full commitments from its young people to develop the country further.

The increasing number of unemployed young workers due to not having working experiences indicates a sign that the government needs to improve the situation in order to achieve healthy economic growth. Laws that deprive young workers of their rights need to be reviewed, as having working experiences require youth to experience work first.

Future research projects are therefore must be directed for designing the entrepreneurship module, as well as tackling policy issues in order to strengthen the effectiveness of the advisory system. Probably, this measure is the most realistic measure to be taken by IIUM or any other higher education in reducing graduates' unemployment rate.

It is also suggested to foster the culture of connectedness to the undergraduates. As they get closer to employment, university often becomes more impersonal and isolating. The advisory system should offer a structure to meet students' developmental needs in line with their career aspirations.

\section{Conflicts of Interest}

The authors declare no conflicts of interest regarding the publication of this paper.

\section{References}

Ahmad, R. H. (1998). Educational Development and Reformation in Malaysia: Past, Present, and Future. Journal of Educational Administration, 36, 462-475. https://doi.org/10.1108/09578239810238456

Audretsch, D. B., \& Thurik, A. R. (1998). The Knowledge Society, Entrepreneurship and Unemployment. University of Illinois at Urbana-Champaign's Academy for Entrepreneurial Leadership Historical Research Reference in Entrepreneurship.

Audretsch, D. B., Carree, M. A., \& Thurik, A. R. (2001). Does Entrepreneurship Reduce 
Unemployment? Tinbergen Institute Discussion Paper 01-074/3.

Baskaran, R. (2009). 2009 Handbook for Employers and Employees in the Private Sector Malaysia (21st ed.). Malaysia: Digest Review.

Bolton, B., \& Thompson, J. (2000). Entrepreneurs: Talent, Temperament, Technique. Oxford: Butterworth Heinemann.

Chew S. G. (2005). Transition from School to Work: Individual Life Courses within Social Structures. US: Marshall Cavendish Academic.

Chew, S. B., Lee, K. H., \& Quek, A. H. (Eds.) (1995). Education and Work: Aspirations of Malaysian Secondary School Students. Kuala Lumpur: Fakulti Pendidikan, Universiti Malaya.

Chong, L. K. (2010). Education: Let's Set It Right. http://www.nst.com.my/nst/articles/20100908000851/Article/

Dangolani, S. K. (2011). The Effect of Information Technology in the Entrepreneurship. Social and Behavioral Sciences, 30, 10-12.

Dictionary of the English Language, 1996, Geddes andGrosset Ltd.

Fatimah, D. (2007). Pengurusan Sumber Manusia: Persepsi Majikan Terhadap Graduan Malaysia. Menangani Perubahandan Pembangunan. Kuala Lumpur: University Malaya Press.

Hamisah, H. (2008). Human Resource Practitioners Are Bracing for News of Job Cuts, Although the Weakening Business Activities within Malaysian Industries Have Not Resulted in Layoffs Yet.

http://www.btimes.com.my/Current_News/BTIMES/articles/30LABOUR/Article/index html

International Labour Office (2005). Youth, Pathways to Decent Work, Promoting Youth Employment: Tackling the Challenge. In International Labour Conference.

International Labour Organisation (2001). Youth and Work: Global Trends. Geneva.

Jennings, L. B., Parra-Medina, D. M., Messias, D. K. H., \& Mc Loughlin, K. (2006). Towards Critical Social Theory of Youth Empowerment. Youth Participation and Community Change, 14, 31-55.

Lai, C. (2010). Diversity in Organizational Culture. http://www.ehow.com/about_6540118_diversity-organizational-culture.html

Leidenberger, J., \& Stoltz-Loike, M. (2009). Diversity in the Workplace. http://www.zeromillion.com/econ/workplace-diversity.html

Marohani, Y. (2006). Penyediangraduan Untuk Pasarankerja Global. In A. R. A. Rashid, S. Hussin, \& A. J. Othman (Eds.), Halatuju Pengurusan: Sumber Manusia dan Kerjaya. Kuala Lumpur: Utusan Publications \& Distributors Sdn. Bhd.

Mohamed, A., \& Abubakar, S. Y. (2011). Strengthening Entrepreneurship in Malaysia.

MohdLazim, A. (2009). Identifying the Generic Skills amongst Malaysian Undergraduate Students: An Analysis of Gender Differences. Jurnal Teknologi, 50, 11-20.

Montross, D. H., Kane, T. E., \& Ginn, R. J. (2004). Career Coaching Your Kids: Guiding Your Child through the Process of Career Discovery. Mountain View, CA: Davies-Black Publisher

Rabiatul, N. J., \& Intan, S. H. (2007). Gejala Ekstrem Remaja. Selangor: JRAS Corporation Sdn. Bhd.

Rashid, A. R. A. (2006). Ciri-cirigraduan yang marketable danberdayamajuuntukkemajuankerjayaabad ke-21. In A. R. A. Rashid, S. Hussin, \& A. J. Othman (Eds.). Halatuju pengurusan: Sumber manusiadan kerjaya. Kuala Lumpur: Utusan Publications \& Dis- 
tributors Sdn. Bhd.

Rashid, A. R. A., Hussin, S., \& Othman, A. J. (2006). Halatuju Pengurusan: Sumber Manusiadan Kerjaya. Kuala Lumpur: Utusan Publication and Distributors.

Rohaiza, A. R., Saodah, W., Mariam Adawiah, D., TunkuMohar, T. M., Shukran, A. R., Mohd. Feham, M. G., Ainol, M. Z., Wan Rohaida, W. H., Aznan, Z. S., \& Mohd. Yazid, Z. K. (2014b). IIUM Tracer Study 2013. Selangor: Alumni and Career Services Division, International Islamic University Malaysia.

Rohaiza, R. (2014a). Youth Employability and Work Attitudes. International Journal of Science Commerce and Humanities, 2, 190-202.

Rugaber, C. S. (2010). Jobless Find Old Jobs Now Need More Skills. http://www.nst.com.my/nst/articles/16jobi/Article

Rusch, F. R. (2008). Beyond High School: Preparing Adolescents for Tomorrow's Challenges. Pearson, NJ: Pearson Merrill Prentice Hall.

Shukran, A. R., Saodah, W., Hariyati, S. A. M., \& Noor, A. M. N. (2004). Graduate Employability 2003. Kuala Lumpur: Alumni Relations Section, IIUM.

United Nations (2001). World Employment. New York: United Nations Statistics Division.

United Nations (2010). World Employment. New York: United Nations Statistics Division.

United Nations (2015). World Employment. New York: United Nations Statistics Division.

Wye, C. K., \& Rahmah, I. (2010). Labour Market Structure in Malaysia: Pre- and Post-Market Gender Comparison. International Journal of Academic Research in Business and Social Sciences, 2, 259-284.

http://papers.ssrn.com/sol3/papers.cfm?abstract_id=1510006

http://www.businessdictionary.com/definition/entrepreneurship.html

https://www.dur.ac.uk/hatfield.college/undergraduate/support/

https://www.humanresourcesonline.net/malaysias-workforce 